\title{
Integrating Divergent Representations of Place into Decision Contexts
}

\author{
Damon M. Hall, Texas A\&M University \\ Susan J. Gilbertz, Montana State University-Billings \\ Cristi C. Horton, Tarleton State University \\ Tarla Rai Peterson, Texas A\&M University
}

\begin{abstract}
260 words

Places are spaces that humans have bound, ordered, and defined by communication. Such representations are culturally situated and inherently involved in the production of legitimate knowledge. Place representations slice space into pictures of the world that simultaneously flatten and deepen space within public discourse. Flattened space is the bounded site where place is displayed as generalizable, accessible, calculable, and isometric. Deepened space displays the experience of place through artistic or poetic accounts. Whereas flattened representation of place removes the subject to accurately replicate the reality of place, deepened representation of place focuses on active participation of the experiencing subject in place. Conflict arises when groups must reconcile a site's simultaneously deepened and flattened representations. Thus, attending to how place is represented in various natural resource management (NRM) decision contexts is critical to the potential success of NRM. Since managers and decision makers cannot fully control the representation of place, they need to understand how place representation connects meaning and language to culture via practices of everyday life. We offer a cultural inventory as a tool that can facilitate development of such an understanding. The cultural inventory emerged from informant-directed interviews with landowners, recreationalists, civic leaders, and agriculturalists along the Yellowstone River. After interviewing resource users, we analyzed interview transcripts to discover how these residents represented their place, focusing on
\end{abstract}


discursive frames that flattened and deepened it. Our analysis suggests how a hermeneutics of place representation provides NRM advisors, planners and other decision makers with a conceptual framework that may help them integrate divergent place representations into decision contexts, leading to more effective management.

\section{Introduction}

Environmental conflict often arises because divergent representations of a shared resource clash. Representations of place_-as containers for groups' identities and interests—become sites of struggle for control over the interpretive frames that direct land use and planning. A shared vocabulary helps groups of people work together (Burke 1959; Peterson 1997), and agreement on a shared set of terms for representing a place endows decisions about how to manage that place with legitimacy. Because managers cannot fully control the social dynamics of how groups represent place, they need to understand how place representation connects meaning and language to culture via practices of everyday life and the practical consequences of those practices. An awareness of this easily overlooked social compact is useful for framing decisions that emerge seamlessly from representations of place offered by local stakeholders. Place meanings can be used as rich (thick) demographic data, and observed in their politically-engaged form as representations which contribute to the struggles over legitimacy in decision making. Because natural resource management (NRM) includes both symbolic and material resources, managers need to understand both. This chapter focuses on symbolic dimensions of NRM, as they emerge through people's taken-for-granted communication. We offer the cultural inventory as a tool to enable managers to understand how people connect symbolic and material resources as part of their representation of place. In response to NRM needs for the Yellowstone River, we 
designed and conducted a cultural inventory to discover and document dominant representations of that place. The cultural inventory began as any inventory, with identification of available resources (in this case human resources), and then moved to production of a data base describing how these resources function. The primary function we sought to understand was place representation. After identifying major groups of resource users, we conducted informantdirected interviews with landowners, recreationalists, civic leaders, and agriculturalists that live along the river. We then analyzed the interview transcripts attending to how these residents individually and collectively represented their place. Our analysis suggests how attention to localized cultural discourses provides NRM advisors, planners and other decision makers with a conceptual framework that may help them integrate divergent place representations into decision contexts, leading to more effective management in and of place.

In this chapter, we contextualize the cultural inventory by beginning with a broad discussion of how processes of place representation contribute to place meaning. We then examine the functions and forms of place representation, threading together scholarship emphasizing relationships between place and discourse. Using Edward Casey’s (2002) framing of the practices of place representation, we examine resource users' flattened and deepened representations of the Yellowstone River, including how discourse has integrated the river with local and cultural meanings, political strategies implicit in the discourse, and unexpected consequences. After describing the results of the cultural inventory, we end with suggestions for how decision makers can encourage place representation frames that enable diverse resource users to creatively negotiate their identities and interests in the resource

\section{Place Meanings and Place Representation}


That people connect to place in significant and lasting ways is established. Whether this connection is based on a utilitarian experience of place such as physical sustenance, security, and dependency or an experience of place through a sublime encounter with nature, people physically depend upon and affectively attach to place. Natural resource scholars and managers have examined the expression of place meaning and its significance. These discussions of place meaning fit within research on the human dimensions of NRM, and focus attention on how people come to value and understand natural landscapes. The analysis of place meaning aims at discerning landscape valuation in terms beyond but not mutually exclusive from economics (Williams et al. 1992). As such, NRM scholarship operationalizes theories of place from cultural geography (i.e. Tuan 1974, 1977; Cosgrove 1998), phenomenology (i.e. Relph 1976; Casey 1993, 1998, 2002), and social and environmental psychology (i.e. Fried 1963; Proshansky et al. 1983; Altman and Low 1992) into metrics of place meaning expressed in terms of attachment, sense of place, place identification, and others (Patterson and Williams 2005). Broadly speaking, research that attempts to account for the importance of place to people tends to focus on felt experience of place and/or the communication of a sense of place into place meaning. These models of place attachment are primarily rooted in social and psychological theories of attitudes, values, and behaviors and include constructs such as place bonding (Jorgenson and Stedman 2001), place dependence (Stokols and Shumaker 1981), and combinations of attributes such as place familiarity, belongingness, identity, dependence, and rootedness (Hammitt et al. 2006). The social psychological basis (e.g. Ajzen and Fishbein 1980) undergirding these studies connects how people perceive and value place as meaningful to human behavior-a notion that resonates throughout the annals of place literature (c.f. Tuan 1977; Soja 1989; others). Linking behavior and value relations with place meanings has proven useful for informing recreational 
opportunity planning (Kaltenborn and Williams 2002), understanding resource conflicts (Cantrill and Senecah 2001; Cheng et al. 2005), and incorporating stakeholder sensibilities into decisions related to changing land uses (Davenport and Anderson 2005; McCool et al. 2008). Leveraging resource users' affective valuation of place meaning as it indicates use-value and behavior can inform decision making processes, practices, and outcomes.

Although the psychometrics of place meaning are useful from a socio-demographic perspective, cataloging and using persons' expressed place meanings is problematic first from a communication theory perspective and second when we consider how these meanings enter the political realm of NRM. The context theory of meaning (Richards 1936) suggests that communicated meaning is multiple, flexible, historically bound, based on normative and habitual conventions, and inherently interconnected and interdependent with its context. This constrains the transferability of place meanings between scientific and public realms because scientific discourses require generalized (context-transcendent) subject-free frameworks (Flyvbjerg 2001) which are difficult to reconcile with individuated context and subject-dependent affective accounts of place. No matter how accurate the symbolic system of description may appear, there is no one-to-one abstract referencing that can account for people's place meanings with consistent precision because meaning is context-dependent and unique in each voice, group, culture, moment, and situation (Wittgenstein 1958). For each person, the picture of the universe shifts as place description moves from tongue to tongue (Carroll 1956). There is no single authentic way of generalizing place meanings (Abram 1996). As such, scholars must question the utility of searching for an orderly semiology of place meanings that would render multivocal and hypercomplex place meanings commensurate (Lefebvre 1991; Casey 2002). This problem of incommensurability of place meanings first with one another and then with scientific discourses 
is a matter of epistemology (Williams this volume) that needs to be explored if managers are to use the concept of place as part of an effective decision calculus.

This chapter focuses on the political challenges of using place meaning to inform decision making, exploring what happens when place representation enters the political realm. In addition to its immediately practical value, however, understanding how place representation functions in the political realm can improve our ability to negotiate the conceptual problems of irreconcilable place meanings.

When we consider the interests, mandates, and stakes involved in the political realm of NRM, communicated place meanings assume a strategic form and function. In decision making, place meanings are used as tools for action that vie for control over the truths told about a place, in order to influence management to make changes or preserve a vested status quo. Place meanings become communicated with purpose in representations of place which take a different form than individuated expression of felt value. Groups construct and advance representations of place that do work for their advocates by framing and naming the contexts of decision making, what is important/unimportant, and what should be included/excluded as valid information. The representation of place performs a constitutive function in the politics of managing shared natural resources. Places as spaces that humans have bound, ordered, and defined by communication (Sack 2001) are linguistically represented in legal, scientific, managerial, and public discourses. Thus in decision making settings the study of place is not only concerned with accounting for stakeholder's place sensibilities so that managers may navigate and anticipate buy-in or resistance to decisions. Attention to place also involves examining the social and cultural practices of socially-agreed upon representations of place within local political and managerial discourses. How publics and decision makers represent place- - how it is named, 
labeled, mapped, and illustrated—in decision spaces has both instrumental and constitutive functions. Representing place organizes a perspective of reality that legitimizes certain cognitive schemes, and excludes others. It produces what we know about a particular landscape, what actions are proper and improper within its boundaries, and how we come to value it. How we represent place not only delineates (points to) a place by highlighting its borders but also makes a statement about its character, utility, past, future, and how it should be managed.

\section{The Production of Place Discourse}

How we speak and write about place and the words we assign to it constitutes much of how we think and act in place (Lefebvre 1991; Tuan 1991; Cosgrove 1998; Stokowski 2002). A number of scholars have examined the connections between communication and place from language and place making (c.f. Meinig 1979; Lefebvre 1991; Tuan 1991; Greider and Garkovich 1994; Herndl and Brown 1996; Sprin 1998) to discourse and management (c.f. Berdoulay 1989; Myerson and Rydin 1994; Dryzek 1997; Stokowski 2002; Norton 2005; Wolf and Klein 2007) with each providing helpful frames for understanding how communication shapes our interactions with place. These scholars argue that representations of place in public discourse make sense of complexity, unite disparate persons, anchor collective memory, and give authority to subscribers.

Representation of any sort connects meaning and language to culture via practices of everyday life. Stuart Hall describes representation as the production of meaning through language, or "the link between concepts and language which enables us to refer to either the 'real' world of objects, people or events, or indeed to imaginary worlds of fictional objects, people and events” (Hall 1997, p. 17). Such representations are kept alive through 
communicative practices like storytelling because they function as a source of explanation, comprehension, thought, meaning, and beyond (Entrikin 1991; Stegner 1992; Smith 1999; Carbaugh and Rudnik 2006). Stories representing place include mostly cogent logics, a structural and temporal order and implied values.

Because people’s discourse simultaneously structures and expresses their understanding of the experienced world (Burke 1969; Peterson 1997; Lakoff and Johnson 2003), identifying certain places through the naming and labeling of space simultaneously constructs and communicates what behaviors are allowed and which practices are proper and improper in that space (de Certeau 1984). Like the setting of any story, the way place is described partially determines what actions are likely to occur there (Burke 1969; Cronon 1992). Henri Lefebvre (1991) likens representations of space to street signs that are intended to guide, direct, command, and orchestrate behavior. They "serve to distinguish, but not isolate, particular spaces, and in general to describe a social space. They correspond to a specific use of that space and hence to a spatial practice that they express and constitute” (Lefebvre 1991, p.16). By naming and framing normative practices appropriate for particular sites, place representation reinforces some management options while excluding others.

Managed natural resource spaces are places because they bind the site conceptually in order to think and speak about place as well as use it (Lefebvre 1991). The representation of place, then, is a cultural practice whereby people use various modes of communication to construct and adjust legitimate uses of space (Rose 1994).

Because people depend on communication to enable cooperation in the face of division, they seek a common language to conceptualize, discuss, and manage the natural systems required to sustain life (Burke 1959; Peterson 1997). Terms used for managed sites divide up the 
world into accepted names and conceptual representations of space necessary for identifying and referencing particular spaces (Rydin and Myerson 1989; Whatmore and Boucher 1993). The primary effect of any discursive representations is that they define and produce the objects of our knowledge (Foucault 1972). Any community (e.g. governing agency, industry, stakeholder group, etc.) has a vocabulary of terms that frame and position relations of everyday human life to the natural world and guide decision making. As such, "language reveals much about a profession, about its preoccupations, about the social, political, economic, and scientific forces that bear down upon it, and also about its readiness to confront those forces effectively" (Guttenberg 1993, p. 1). The discourse of NRM has relied upon technical knowledge to understand and manage the natural environment within institutional, legal, and bureaucratic capacitates and frameworks. This discursive frame has bounded the ways NRM professionals conceptualize place representation in ways that may have placed unwarranted limitations on their decision possibilities.

\section{Place Representation by Flattening vs. Deepening}

Two terms especially useful for our discussion of place representation come from Edward Casey’s (2002) analysis of place representation in landscape paintings and maps. Casey (2002) argues that representations of place slice up space into pictures that flatten and/or deepen the worldplace. Representations that flatten the world make sense of complexity by flattening landscape's idiosyncrasies into gridlines, contours, and other classifications with the aim of accurate orientation, definition, and utilization of place. Flattened space is the bounded site where place is displayed as generalizable, accessible, calculable, and isometric. This flattened space is the realm of abstract space or space as object according to the isotropic categorizations 
of Newton and Descartes (Lefebvre 1991). Space in this form is represented in Euclidian geometry and is often conceptualized without the potentially confounding presence of human subjects, which could threaten the objective representation of reality. An alternative way of representing place is by deepening it to explore the subjective experience of place, often through artistic or poetic accounts. Where flattened representation of place removes the subject from place to ensure accurate replication of reality, deepened representation of place is more interested in active participation of the experiencing subject in place than in creating a replicable account. Deepening space involves felt meaning of the subject living in place, as opposed to flattened accounts that situate the subject above place.

Both deep and flat representations of place are social practices. As such, they unite disparate persons, anchor collective memory, and give authority to subscribers. Since discourse simultaneously structures and expresses a perception of the experienced world, the naming and labeling of space constructs and communicates which practices are appropriate or inappropriate for each place. Conflict arises when groups must reconcile a site’s, sometimes highly divergent, deepened and flattened representations. Thus, how place is represented in various decision contexts is critical to the potential failure and success of managerial efforts.

\section{The Yellowstone River Cultural Inventory}

The U.S. Army Corps of Engineers (Corps) regulates riparian corridor activities under the authority of Section 10 of the Rivers and Harbors Act and Section 404 of the Clean Water Act (CWA). Since assuming CWA permitting duties in the mid 1970's, the Corps has processed a total of 156 permit actions for the upper Yellowstone River (Park County, MT). Over two-thirds of the permit actions occurred during or after two consecutive "100 year" floods occurred in 
1996 and 1997 (Auble et al. 2004). The high volume of permit requests for bank stabilization projects to control flooding and prevent erosion prompted a grassroots call for a cumulative impact study of the potential environmental and ecological consequences of this channel modification. A moratorium on bank stabilization permitting was enacted until the cumulative effects were examined and permitting processes could be reevaluated.

The cumulative effects study focused on physical features, biological inventories and historical floodplain mapping of the Yellowstone River. When the Corps decided to include social and cultural dimensions as part of the cumulative effects study, we suggested a cultural inventory that would be analogous to the biological inventories.

\section{Historical context}

In 1806, on a canoe made from a cottonwood tree Captain William Clark traveled down the Yellowstone River to meet Meriwether Lewis at its confluence with the Missouri for the return trip to Washington D.C. (DeVoto 1953). The objective of their journey was to map and describe the newly purchased lands of the Louisiana Purchase for purposes of delineating the riverine highways of the coveted Northwest Trade Passage between the east and west coasts of North America. Lewis and Clark characterized the landscape with maps from survey measurements and described the natural resources via journal accounts of their subjective experiences. For President Jefferson and the U.S. Government, Lewis and Clark presented the landscape in both maps which used math and geometry to flatten the topographic landscape to paper and journal descriptions to deepen the landscape by chronicling the plants and wildlife, the aboriginal peoples and practices, the weather and the topography they experienced. Their report was the first Euro-American documentation of the Yellowstone River. 
The Yellowstone River remains much as it was when Clark traveled its length; the longest undammed river in the United States. This characteristic affords scenic and recreational amenities which attracts visitors and residents. At the same time, much about this place has changed. The river's characteristic seasonal flooding, for example, is problematic for riverfront homes and farmland. In a single flood event, hundreds of acres of bordering land may be lost or gained by the movement of the river's channel. We conducted a cultural inventory exactly 200 years after Lewis and Clark's now famous expedition. We spoke with 313 riverfront landowners and users (Table 1.0) along its entire length, from the point where it leaves federal jurisdiction in Yellowstone National Park to its confluence with the Missouri River (Gilbertz et al. 2007). To ensure appropriate distribution of stakeholder interests and account for geographic differences we divided the river into five geographic reaches. Those whom we spoke with depicted the river, its different phases, spots, forces, and character throughout the seasons. As a complement to the interviews, we gathered related documents, engaged in participant-observation, and performed thematic analysis of all texts (Peterson et al. 1994). We analyzed and organized these comments into a report of the cross-sectional themes that ensured the inclusion of each unique perspective using 1700 quotes from participants to illustrate and provide evidence for our findings (Gilbertz et al. 2007).

\section{Inventory of place representations}

Words and phrases struggle to simultaneously reflect truths about place and truths to the felt place experience. Those who live with the Yellowstone River project a hyper-complex assortment of representations of both deep and flat elements onto the river. Meaningful aspects of people's lives contribute directly to the spectrum of representations they give the river: 
occupations, hobbies, relations with the land, loves and fears, education, expertise, daily

practices, river uses, family legacy, daily activities, senses of history, pasts and childhood, geographic reach along the river, proximity to its waters, relations to area laws, economies, and politics, etc.

Among the local vernacular that heaps meaning, value, and purpose onto this resource, we found three dominant representations. Most people represented the river as: the lifeblood of the valley, a great playground, and/or a national treasure. We briefly summarize these dominant constructions, and then provide more detailed description of one case to illustrate how place representations enter the political sphere and may incur unexpected consequences upon the natural resource.

\section{1. "The Lifeblood of the Valley"}

"It's the lifeblood of the Yellowstone Valley, that's all there is to it." -Agriculturalist Perhaps the most dominant image of the Yellowstone River among agriculturalists, recreationalists, civic leaders, and other long-time residents is that of the river as "the lifeblood of the valley," or an essential element in the creation and maintenance of valley life. One civic leader explained, "the Yellowstone River is the lifeblood as far as Ag and recreation goes. It is what draws people here. It is the main artery.” Representing the river as “lifeblood” flattens and objectifies it into economic and legal structures that include food crops and other commodities, businesses, and services. A civic leader noted that the "vast majority of the economy is within the boundaries of that river.” The river supplies irrigation water for crops, livestock, and drinking water for humans. As a driving force for development of towns, goods, and services, the river offers communities a “lifeline” by making water available in the semi-arid landscape: The river 
as lifeblood evokes flat descriptions of biophysical forces. Residents understand that the valley's "productive agricultural lands" relate to the river's dynamic forces of historic seasonal flooding. The "June rise" ensures the fertility of the fields and the regeneration of the bottomland cottonwood forests. The river also provides habitat and nutrients for fish and wildlife while maintaining humidity throughout the seasons in this arid landscape. As a civic leader summed it up: "Of all the natural things that occur, [the river] is the most important thing. It provides water for drinking, flood irrigation, and recreation. It is the lifeblood of our community."The Yellowstone River is the lifeblood as far as Ag and recreation goes. It is what draws people here. It is the main artery through Paradise Valley for sure (Civic Leader).

Descriptions of the Yellowstone as the lifeblood of the valley also include deep subjective representations. One agriculturalist, for example, analogized to his own body when telling us that the river "is like having an artery in your body. It is a vital part of this valley. It is the lifeblood of the valley." Nonlinguistic images and practices also play an important role in deep representations of the place. Everyday operations raising sugar beets, spring wheat, winter wheat, alfalfa, and others irrigated crops are passed down from grandparents and parents to children. The rhythms of flood irrigation practices are represented as part of the lifeblood. Resource users talked of opening and closing the ditch gates, monitoring the furrows to ensure optimum flow, and pulling their irrigation boots off and on. They pointed out everyday sights such as ditch hoes and other machinery in the fields, all operating on specific increments of time. These felt practices, sights, norms, knowledges, phrases, and vocabularies are ingrained in the foundation of community and cultural values, and they represent the river as a provider. From this perspective, resource users expressed an ethic of protecting the river as a means of support, which included preserving access rights to the water, whether for irrigation or for 
recreation.

\section{2. "A Great Playground"}

"There is a lot of river there. It is a huge asset to this state. There are so many opportunities. It is a great playground." -Residentialist

A second dominant representation of the Yellowstone resonates with, at the same time it contrasts against, the lifeblood metaphor. This is the representation of the river as "playground," or a place to play and relax. Informants represented the river as a place that provides users with a refuge from the stresses of everyday life. The playground representation builds on the terministic value of sharing a name with Yellowstone National Park. A civic leader explained that, "people have a picture of what Yellowstone Park is even if they have never been there. I describe it [Yellowstone River] as an extension of Yellowstone [National Park]. You attach things like the fishing culture, the hiking, the outdoor mountain recreation.” This representation of the Yellowstone River as playground is reinforced by association with the Park's iconic images, such as the Lower Falls, the Grand Canyon of the Yellowstone, and Yellowstone Lake. Because Yellowstone National Park is known as a wild place where nature has been left relatively intact, so to do recreationists hope to successfully justify increased protection for the river.

Playground images typically begin with a deep account of recreational bliss: An experience of solitude, wildlife, peace, rest, natural beauty, or somehow encountering the wild. As one recreationalist enthused, "the Yellowstone is my cathedral. That's my church; that's my spirituality.... It's where I charge my batteries. It's my connection to the natural world.” Many see river recreation as a way to regain their sense of well-being whether it is through fly-fishing the cold waters or bait fishing the warm waters; hunting deer, waterfowl, pheasants, wild 
asparagus, mushrooms, or agates; hiking, bird-watching, boat floating, inner tubing, or swimming; or just sitting and watching the water. Although recreationists frequently used the playground metaphor, so did informants representing other user groups. One local resident explained:

I've always gravitated towards it because it's always relaxed me....My church is the river....The fog comes up off the water....The sun pops up and your line is singing out there and you look down and see the little crystals on it, then I look down and see a herd of elk crossing a couple hundred yards from me. It gives you....It's what drug addicts are, the reason they're drug addicts....It gives you that feeling...with no side effects,...other than you're hooked....I'm not leaving here....This is a place to keep forever.

The deep representation of felt experience when fly-fishing, hunting, boating, etc., is thoroughly intertwined with flattening representation, as the place becomes an object of business and a legal matter of recreational permitting and licensing, bag limits, designations of special waterfowl habitat refuges, conflicts between users, and Montana's stream access law. Flattened representations depict the river as a producer of revenue for outfitters, guides, private landowners, and affiliated equipment rentals, fishing shops, hotels and restaurants. These representations allow calculable financial valuations of the river's recreational assets and related economic impacts at specific points along its length. The salience of the playground metaphor drives riverfront development and the local real estate industry. The gridlines and contours that define this place through relatively flattening representational practices guide motor boat restrictions, the development of public river access points, state investments in the management of fisheries, and further flattening representation (map making) for boating and angling. 
The economic motif of the playground metaphor is most visible among residents and other resource users of the western cold-water stretches of the river where tourists travel through Paradise Valley, which lies near the northern entrance of Yellowstone National Park. Post cards, calendars, brochures, and varied tourist kitsch depicting the Yellowstone as a sublimely wild river are sold throughout that stretch of the river. Because resource users explicitly affiliate the river with Yellowstone National Park, texts centered on the Park as a tourist destination are available to reinforce the playground place representation for the Yellowstone.

Those who represent the river as a playground often share a dedication to the uniqueness of the river and are advocates of keeping the river free-flowing. Their stated desire often included maintaining and improving the ecological health of the river. While those who represent the Yellowstone River as lifeblood may view erosion as a threat to be mitigated or a danger to protect against, those who represent the river as a playground respect natural processes such erosion, and argue they should generally be allowed to proceed without external controls. They want to see that others respect the river's resources, residents who live along the river, and other users. They worry that the river is getting crowded and that access across private lands is becoming more difficult to attain.

The deep representation of the river as a place of play was reinforced by Norman Maclean's book (1976) and movie (1992) A River Runs Though It. Although the story was about the Big Blackfoot River, the movie was filmed in Paradise Valley on the Yellowstone River. The cinematographer won an Oscar for the orchestration of the images of this mountain valley and braided river. One result of what some locals disdainfully call "The Movie,” was that fly fishers flocked to the Yellowstone River in hordes. Leighton (1998) describes this phenomenon as a "battalion of outfitters, guides, and other full- and part-time trout bums" who are eager to exploit 
the region's resources in the "final Gold Rush,” (p. 46). Partly in response to public enthusiasm generated via the movie, the playground representation has influenced home site preferences and the hierarchy of property values.

\section{3. “A National Treasure”}

"I would like to keep the Yellowstone a free-flowing river. It is a national treasure." Recreationalist.

The Yellowstone River is the longest undammed river in the United States. The exclusivity associated with this material fact contributes to its representation as a national treasure, and to the frequent inclusion of the word "wild” in descriptions of the river. Informants articulated this special characteristic of the river as a rarity that enhances the quality of experience for users and quality of life for residents.. The National Geographic Magazine labeled the Yellowstone River as "the last best river" (Chapple 1997) borrowing from a Montana state tourism campaign that promoted the state as the "last best place.” Local residents from across the political spectrum are especially protective of "their" river, dating at least to the proposed Allen Spur Dam in 1958, which locals viewed as threatening to both natural amenities and private property rights. Many of our informants used the idea of the river as a unique national treasure to explain why most attempts to control the river were inappropriate. As one recreationist said, “you don’t want to dam this river. This is one of the-THE-last wild river in Montana, and it may be the last wild river in the nation. There is no dam on the Yellowstone, and we really don't want a dam on the Yellowstone.”

As with any national treasure, The Yellowstone River is often represented as needing protection. One resident articulated his obligation this way, 
I guess living next to the Yellowstone; you get such a loyalty to it. It is something that has to be protected and you can’t give it away...It just got into a real almost a spiritual thing - when you live next door to it, it becomes something bigger than property rights and that sort of thing.

His felt experience with the river led to a deepened representation for this place. Many informants similarly expressed their sense of "responsibility," or "duty," to safeguard the river. By representing the river as a national treasure, our informants elevated the importance of protecting it as a rare remnant of the truly wild in nature. Residents often spoke about how "lucky" and "privileged" they felt to live along the river. "You know, every other river in the country is dammed, and it is nice to have something that's wild in your backyard” (Recreationalist).

Of course, these deepening representations of place interact across stakeholder categories, uniting streamside residents, agriculturalists, and recreationalists in appreciation for this place. People's descriptions interconnect metaphors of lifeblood, playground and national treasure to represent the place. Their comments often demonstrate an awareness of the place as a system that includes people such as themselves, as well as those who are different. As one recreationalist explained,

I'm so one with the river, and it's moods that it becomes my spirituality, ... it has different character around every bend - it acts differently in the spring than it does in late summer, it’s different in the winter, it's an incredibly complex ecosystem, that if one person in their lifetime can figure out a little bit of it, is quite an accomplishment - and that's what transcends the actual fishing. 
The national treasure metaphor also allows people to represent the Yellowstone River in flattened form. In this case, the financial treasure becomes the central focus, and discussion swirls around cost-benefit assessments of water storage, flood protection, and electrical power generation potential. The river's (relatively) free-flowing status also makes it always vulnerable to flattened images that de-value many of the felt experiences described above. Subjective description of the river’s “spirituality” for example, are of little use if the river's value is predicated solely on the dollar value of its use for irrigation or the dollar cost for prevention of flooding, . Whether described as the lifeblood of the valley, an incredible playground, or a national treasure, the Yellowstone River emerged as a place with distinctive deepened and flattened characteristics, and these characteristics may offer clues for NRM.

\section{Conflicting place representations in the public realm}

Different representative images of the same place can clash. The battleground is in public conversation where each seeks to reframe the place to create 'proper' ways of thinking about access rights, quality and quantity of the resource, management authority, and what is considered legitimate use of the resource. Competing representations of place "are the meeting points of tremendous pressures coming from rival word-users, each of whom would like to appropriate the word for his [sic] own purposes”(Guttenberg 1993, p. 6). Competing perspectives of a shared site and the coordination of competing interests is often dubbed the politics of place (c.f. Cooke 1984; Jackson 1987; Kemmis 1990; Norton and Hannon 1997; Honadle 1999; Yung et al. 2003; Cheng et al. 2005; Norton 2005). The politics of place is then, in large part, the clash of vested and vetted socially-constructed representations of place.

Past management initiatives for the Yellowstone River illustrate this clash, and resonate in contemporary accounts of river users. In 1958, a state delegation prompted by U.S. Senator James E. Murray (Montana) and the U.S. Bureau of Reclamation (Bureau) first offered a strategy for using the Yellowstone River to provide water and energy security by proposing the construction of a water-retention dam at a narrow point in Paradise Valley (Nolt 2007). From the 
agencies' flattened representation of the place, the valley was ideally shaped for a dam (Wheelwright 1978). The 380-foot tall Allen Spur Dam was to house a 250 MW power plant and a 30-mile reservoir covering 20,000 acres (Nolt 2007). A grassroots campaign soon developed around residents' recreational and agricultural practices that provided an alternative deep representation of the river as a site of meaningful experiences important to Montanans. By 1963, Park County Commissioners, the Park County Rod and Gun Club, and the Farm Bureau joined together in opposing the dam, citing concerns over the loss of farmland and fish and wildlife habitat (Nolt 2007). In the face of organized local opposition, interest in the proposed dam subsided until the energy crisis of the 1970s and the need for water resources for the Fort Union coalfields.

Recreationalists opposed the dam because it would have flooded the Yellowstone's best trout fishery, the source of several nutrient rich spring creeks where trout spawn including the endangered Yellowstone cutthroat trout (Oncorhynchus clarki). As one participant told us, after they learned of the proposal they resisted the proposed dam by publicly representing the Yellowstone River as a blue-ribbon fly-fishing destination and an ideal location for riverfront vacation homes. Their expressed intention was to interrupt the proposed dam by attracting wealthy fly-fishing enthusiasts to move to the river valley. Filling the valley with expensive vacation homes would discourage the Bureau from siting the dam on the Yellowstone by skewing the cost-benefit-analysis calculations when the federal government considered the costs of necessary regulatory takings. The fly fishing community of Paradise Valley, multiple Greater Yellowstone advocacy organizations, other recreational users and agriculturalists harnessed the symbolic prowess of "Yellowstone" to forward a campaign to save the river and its natural amenities. In addition to grassroots organizing, dam opponents used the media to cover the 
controversy and brought visitors to Paradise Valley, the bed of the proposed reservoir. A 1978 Life article titled "Great River in Crisis" told the story of the proposed dam as a demand for a “30-mile long storage tank” and described the threats to this undammed wonderland alongside full-page aerial color photos of the river's mountain scenery and quotes from a "ruddy-faced Montana cowboy with tears in his eyes” (Wheelwright 1978). The campaign worked. During initial stages of the Bureau’s planning, regional and national outcry combined with a proliferation of riverfront second homes and the values of recreation oriented home owners to prevent construction of the Allen Spur Dam. Twenty-five years later the high numbers of vacation homes in the valley continue to suppress re-visitations of the Allen Spur Dam conversation yet the fly fishing experience has changed. Some participants describe fishing that stretch of the Yellowstone River as floating through a subdivision. Others no longer fish that stretch of the river because of the loss of the wild attributes. Furthermore, annual flooding and the close proximity of new residents' homes have led to the installation of large boulders (riprap) which affect the flow characteristics of the riparian corridor. This rapid rise of development and use leads to the common phrase we heard of loving the river to death. One of the original framers of the strategy to prevent construction of the Allen spur Dam told us that although he was happy to have saved the river, the success of the campaign has now backfired. As he and other participants in the original advocacy campaign explained, their representation of place had worked too well and the continued proliferation of homes along the river is damaging the ecological amenities that preservationist advocates sought to protect.

Participants in the advocacy campaign in opposition to the dam recognized that controlling the dominant representations of place is one means of controlling the symbolic resources of decision making. By representing Paradise Valley in a certain way, advocates 
influenced agency behavior, interpretive frames, and decision making (Lefebvre 1991). As in this example, representations of place regularly "intervene in" and "modify spatial textures" according to a truth-teller's interests (Lefebvre 1991, p. 42). In NRM, political power is actualized through the selection and exclusion of the terms and images used in representation (Bourdieu 1990; Foucault 1994). Opponents of the dam engaged in the politics of place, as they struggled to control the "truths told about a place" to shape acceptable uses and norms so as to exclude the dam.

\section{Reconciling Competing Representations of Place for Decision Making}

Like bank stabilization practices along a wild and moving river, words and images armor the boundaries of our conceptualizations of place. Different interest groups advance representations of place that privilege certain knowledge they believe will stabilize or further their advantage over other equally valid interests (Kemmis 1990; Honadle 1999; Cheng et al. 2005). Any representation, for example, deflects opposing worldviews to protect the preferred image of a place. As riverfront landowners and agriculturalists on the undammed Yellowstone River know; all bank stabilization efforts are temporary. Likewise management cannot entirely control how a managed site is viewed by stakeholder groups and decision makers.

As we followed the Yellowstone River speaking with its residents, listening to their stories, experiencing their practices, and participating in their events, a kaleidoscope emerged. Each participant's mental image and descriptive representation of the Yellowstone was strikingly diverse and yet threaded, sutured, and sewn together by the materiality of the natural system, the legal status of the river as a shared resource, and by vernacular phrases that resonated throughout the community. When we asked participants to describe their place along the river, each 
informant articulated a unique image based on their lived experiences of the river. Responses displayed how participants: (1) perceived the riparian areas, (2) formed their views on flooding and bank stabilization and (3) articulated their interests and desires for future management. To many the river is a "gem, a goldmine, and the golden goose." It is a "wild and free flowing" river that "takes what it wants." It is the "boss" for some and commonly referred to as "the lifeblood of the valley." For others it is a "trashy" and "dangerous" river that takes the lives of people each year; a "killer." Some call it a "monster" and a "problem" while others call it the world's "flyfishing Mecca," a "cathedral," the "last wild fishery," and the "home for wildlife.” One agriculturalist said that "if the Mississippi is Old Man River, the Yellowstone is the Prom Queen.” Our informants used these, and other statements, to represent the Yellowstone River as (1) the lifeblood of the valley, (2) a playground, and (3) a national treasure.

Although we organized our data collection around interest groups and geographic segments of the river, many of the place representations that emerged cut across both locations and stakeholder categories. This is one methodological strength of analyzing how place enters everyday discourse via representation that is potentially useful for decision makers. We chose to emphasize the conceptual representations of place rather than than the classification or categorization of individual informants.. Emphasis on the conceptual constructions of place rather than on speaker classification enables us to reflect more of the complexity in how people conceive, experience, and reconcile place filtered by multiple overlapping representations. Focusing on the multiplicity of truths told about the place rather than on the truth-teller enables decision makers to de-emphasize entrehcned positions and identity based politics.

By shifting attention from personalized symbolic meanings of place to how discourse actively represents place in ways that bind what is legitimate action in that place, the cultural 
inventory offers a way to identify the shared meanings expressed by interest groups, communities, and institutions via representations of place. This redirection towards the representation of place as both deepened and flattened space suggests opportunities for NRM advisors, planners and decision makers to explicitly incorporate multiple meanings, effects, and outcomes into their decision calculus. By taking a dynamic view of place representation, decision makers may become more conscious of the potential impacts of seemingly benign acts of place representation and strategic reframing. Awareness of the dynamism of place representation allows managers and publics to actively participate in the production of legitimate knowledge about shared places via shared vocabularies. .

Managing natural resources necessarily involves the management of symbolic resources. A particularly precarious and daunting task that decision makers must perform within the politics of place is the coordination and management of legitimate information. That place is classified, named, and labeled is necessary for planning and management. This necessity of representation of place is complicated because shared places are discussed and constructed multivocally. Each carries with it diverse perspectives including disciplined scientific lenses, bureaucratic organizational perspectives, multi-generation lived experiences and other resident/nonresident stakeholder interests. The problem that decision makers must overcome is of a rhetorical nature insofar as they must reconcile divergent conceptualizations of landscapes housed in place representation in order to get things done.

Just as managers attend to the consequences of physical actions on managed landscapes, so must they attend to concomitant symbolic actions. Managing natural resource sites requires them to gather and disaggregate deep representations of place to be integrated into flattened managerial frameworks and administrative policies. Managers cannot completely control 
representations of place, but they can study these representations to understand their role in decision making and knowledge formation by asking: What are the dominant representations of this managed place? What are the origins and assumptions of each? How do shared place meanings enter decision making? Which representations clash? What effects do place representations have upon planning scenarios? Why? What are the potential consequences of various representations being publicly approved or rejected? How can representations of place be reconciled in a way that leverages perspectives of place to inform the common management objectives for a site?

Careful reflection regarding representation of place will help managers understand stakeholders' argumentation strategies. Analysis of the representations of place may reveal unintended consequences of certain frames. Mangers may become aware of power dynamics, bring consciousness to stakeholders, actors, and agencies so that they may guard against ideological concoctions, and call attention to strategies of oversimplification, expertise, obscurity, identification, and estrangement. Discursive frames for discussing place representation within decision making vocabularies should be respectful of and accessible to local vernaculars. Members of the local community are valuable allies for implementing resource decisions. Understanding and explicitly including the interests of those involved, and then communicating to landowners and residents within these terminologies may mitigate the off-putting scientific jargon.

In order for decision makers to effectively incorporate place representation into their decision calculus, they must understand it as a participatory construction that both flattens and deepens that space. Place representation includes a (relatively) accurate flattened representation of the abiotic, biotic and social factors coordinating multiple areas of expertise. At the same time, 
they must integrate this understanding with awareness of an imagined deep representation that accounts for desired futures for that place and its communities of users. The difficulty lies in getting the proportions right; and that effort remains always problematic. The flat representation must not oversimplify and be so removed that it disregards the realities of politics or neglects resource health. Deepened representations of place cannot be so personalized that it becomes too focused upon the needs of powerful interest groups or misses other ecological-level processes.

With these cautions in mind, an analysis of place representation can inform the communication efforts and strategies in agency and management choices when representing these places. Place representation also offers NRM an inventive or liberating dimension. Because place is socially constructed, it can socially reconstructed. From this perspective, planning and decision making become sets of practices of creating legitimate discourses that guide the place users. While the practices of place representation seem to entrench polar positions, forcing a choosing of sides, decision makers must remind all participants that there is only one material place to be shared: a single common ground. Managers can use existing representations to invent amicable constructions that bridge dominant existing representations of resource places and promote new ways of seeing place and NRM practices.

\section{References:}

Abram, D. 1996. The spell of the sensuous. New York: Vintage.

Ajzen, I. and M. Fishbein. 1980. Understanding attitudes and predicting social behavior. Englewood Cliffs, NJ: Prentice-Hall.

Altman, L. and S. M. Low, (eds.) 1992. Place attachment. New York: Plenum.

Auble, G.T., Z.H. Bowen, K.D.Bovee, A.H. Farmer, N.R Sexton, and T.J. Waddle. 2004. Summary of studies supporting cumulative effects analysis of upper Yellowstone River 
channel modifications: U.S. Geological Survey, Biological Resources Discipline, Open File Report 2004-1442, 60 p.

Berdoulay, V. 1989. Place, meaning, and discourse in French language geography. In Agenw, John A. and J. S. Duncan, editors. The power of place. London: Unwin Hyman, 124-139.

Bourdieu, P. 1990. Logic of practice. Stanford, CA: Stanford University Press.

Burke, K. 1959. Attitudes toward history. Los Altos, CA: Hermes Publications.

Burke, K. 1969. A rhetoric of motives. Berkeley: University of California Press.

Cantrill, J. G and S. L. Senecah. 2001. Using the 'sense of self-in-place' construct in the context of environmental policy-making and landscape planning. Environmental Science \& Policy, 4: 185-203.

Carbaugh, D. and L. Rudnik. 2006. Which place, what story? Cultural discourse at the border of the Blackfeet Reservation and Glacier National Park. Great Plains Quarterly, 26:167184.

Carroll, J. B. (ed.) 1956. Language, thought, \& reality: Selected writings of Benjamin Lee Whorf. Cambridge: MIT Press.

Casey, E. S. 1993. Getting back into place: Toward a renewed understanding of the place-world. Bloomington, IN: Indiana University Press.

Casey, E. S. 1998. The fate of place: A philosophical history. Berkeley: University of California Press.

Casey, E. S. 2002. Representing place: Landscape painting \& maps. Minneapolis: University of Minnesota Press.

Chapple, S. 1997. The Yellowstone: The last best river. National Geographic, 194: 56-77. 
Cheng, A., L. E. Kruger, and S. E. Daniels. 2005. “Place” as an integrating concept in natural resource politics: Propositions for a social science research agenda. Society and Natural Resources, 16: 87-104.

Cooke, P. 1984. Decentralism and the politics of place: An interview with Raymond Williams. Environment and Planning D: Society and Space, 2: 369-374.

Cosgrove, D. 1998. Social formation and symbolic landscape. Madison, WI: University of Wisconsin Press.

Cronon, W. 1992. A place for stories: Nature, history, and narrative. Journal of American History, 78:1347-1376.

Davenport, M. A. and D. H. Anderson. 2005. Getting from sense of place to place-based management: An interpretative investigation of place meanings and perceptions of landscape change. Society and Natural Resources, 16: 625-641.

de Certeau, M. 1984. The practice of everyday life. Steve Rendall Trans. Berkeley, CA: University of California Press.

DeVoto, B. (ed.). 1953. The journals of Lewis and Clark. Boston: Houghton Mifflin Company. DeVries, B. 2006. Yellowstone River among America’s “most endangered.” American Rivers. 21 October 2006.

Dryzek, J. S. 1997. The politics of the earth. New York: Oxford University Press.

Entrikin, J. N. 1991. The betweenness of place: Toward a geography of modernity. Baltimore: Johns Hopkins University Press.

Flyvbjerg, B. 2001. Making social science matter: Why social inquiry fails and how it can succeed again. Cambridge: Cambridge University Press. 
Foucault, M. 1972. The archeology of knowledge \& the discourse on language. Trans. A.M. Sheridan Smith. New York: Pantheon Books.

Foucault, M. 1994. Power: Essential works of Foucault 1954-1984 (volume 3). Paul Rabinow, series editor. New York: The New Press.

Fried, M. 1963. Grieving for a lost home. In The Urban Condition, ed. L. J. Duhl. New York: Basic Books, 151-171.

Gilbertz, S. J., C. C. Horton, and D. M. Hall. 2007. Yellowstone River Cultural Inventory2006. Sponsored by the Yellowstone River Conservation District Council. Funded by the US Army Corps of Engineers. http://dnrc.mt.gov/cardd/yellowstonerivercouncil/2006culturalinventory.asp.

Greider, T. and L. Garkovich. 1994. Landscapes: the social construction of nature and the environment. Rural Sociology, 59: 1-24.

Guttenberg, A. Z. 1993. The language of planning: Essays on the origins and ends of American planning thought. Urbana, IL: University of Illinois Press.

Hall, S. 1997. The work of representation. In S. Hall, editor. Representation: Cultural representations and signifying practices: Culture, media and identity. Thousand Oaks, CA: Sage, 17-64.

Hammitt, W. E., E. A. Backlund, and R. D. Bixler. 2006. Place bonding for recreation places: Conceptual and empirical development. Leisure Studies, 25: 17-41.

Herndl, C.G. and S. C. Brown. 1996. Green culture: Environmental rhetoric in contemporary America. Madison, WI: University of Wisconsin Press.

Honadle, G. 1999. How context matters: Linking environmental policy to people and place. West Hartford, CT: Kumarian Press. 
Jackson, P. 1987. Social geography: Politics and place. Progress in Human Geography, 11: 286292.

Jorgensen, B. S. and R. C. Stedman. 2001. Sense of place as an attitude: lakeshore owners attitudes toward their properties. Journal of Environmental Psychology, 21: 233-248.

Kaltenborn, B. and Williams, D. 2002. The meaning of place: Attachments to Femundsmarka National Park, Norway, among tourists and locals. Norwegian Journal of Geography, 56: 189-198.

Kemmis, D. 1990. Community and the politics of place. Norman, OK: University of Oklahoma Press.

Lakoff, G. and M. Johnson. 2003. Metaphors we live by. Chicago: University of Chicago Press.

Lefebvre, H. 1991. The production of space. Trans: Donald Nicholson-Smith. Oxford: Blackwell.

Leighton, K. 1998. Great American Rivers: Seasons of the Yellowstone an angler's year. Minocqua, WI: Willow Creek Press.

Meinig, D. W. (ed.) 1979. The interpretation of ordinary landscapes: Geographical essays. Oxford: Oxford University Press.

McCool, S. E., R. N. Clark, and G. H. Stankey. (eds.) 2008. Water and people: Challenges at the interface of symbolic and utilitarian values. Gen. Tech. Rep. PNW-GTR-729. Portland, OR: U.S. Dept. of Agriculture. Forest Service, Pacific Northwest Research Station. 256 p.

Myerson, G. and Y. Rydin.1994. 'Environment' and planning: A tale of the mundane and the sublime. Environment and Planning D: Society and Space, 12: 437-452. 
Nolt, D. 2007. Free river: How the Yellowstone River kept its course. New West, April 7, http://newwest.net.

Norton, B. G. 2005. Sustainability: A philosophy of adaptive ecosystem management. Chicago: University of Chicago Press.

Norton, B. G. and B. Hannon. 1997. Environmental values: A place-based theory. Environmental Ethics, 19: 227-245.

Patterson, M. E. and D. R. Williams. 2005. Maintaining research traditions on place: Diversity of thought and scientific progress. Journal of Environmental Psychology, 25: 361-380.

Peterson, T. R. 1997. Sharing the Earth: The rhetoric of sustainable development. Columbia, SC: University of South Carolina Press.

Peterson, T. R., K. Witte, E. Enkerlin-Hoeflich, L. Espericueta, N. Flora, J. Florey, T. Loughran, and R. Stuart. 1994. Using informant directed interviews to discover risk orientation: How formative evaluations based in interpretive analysis can improve persuasive safety campaigns. Journal of Applied Communication Research, 22: 199-215.

Proshansky, H. M., A. K. Fabian and R. Kaminoff. 1983. Place-identity: Physical world socialization of the self. Journal of Environmental Psychology, 3: 57-83.

Relph, E. 1976. Place and placelessness. London: Pion.

Richards, I. A. 1936. The philosophy of rhetoric. New York: Oxford University Press.

Rose, G. 1994. The cultural politics of place: local representation and oppositional discourse in two films. Transactions of the Institute of British Geographers: New Series, 19: 46-60.

Rydin, Y. and G. Myerson. 1989. Explaining and interpreting ideological effects: A rhetorical approach to green belts. Environment and Planning D: Society and Space, 7: 463-479. 
Sack, R. 2001. Place, power and the good. In Adams, P. C., S. Hoelscher, and K. E. Till. (eds) Textures of place: Exploring humanist geographies. Minneapolis: University of Minnesota Press, 232-245.

Smith, P. 1999. The elementary forms of place and their transformations: A Durkheimian model. Qualitative Sociology, 22:13-36.

Soja, E. 1989. Postmodern geographies: The reassertion of space in critical social theory. London: Verso.

Spirn, A. W. 1998. The language of landscape. New Haven, CT: Yale University Press.

Stegner, W. 1992. A Sense of place. New York: Random House.

Stokols, D. and S. A. Shumaker. 1981. People and places: A transactional view of settings. In J. Harvey, editor. Cognition, social behavior, and the environment. Hillsdale, NJ: Lawrence Erlbaum, 441-488

Stokowski, P. 2002. Languages of place and discourses of power: Constructing new senses of place. Journal of Leisure Research, 34: 368-382.

Tuan, Y. F. 1974. Topophilia: A study of environmental perception, attitudes, and values. New York: Columbia University Press.

Tuan, Y. F. 1977. Space and place: The perspectives of experience. Minneapolis: University of Minnesota Press.

Tuan, Y. 1991. Language and the making of place: A narrative-descriptive approach. Annals of the Association of American Geographers, 81: 684-696.

Whatmore, S. and S. Boucher. 1993. Bargaining with nature: the discourse and practice of ‘environmental planning gain.’ Transactions of British Geographers: New Series, 18:166-178. 
Wheelwright, J. 1978. Great river in crisis: There is too much demand for the Yellowstone's water. Life,1(3): 94-104.

Williams, D. R., M. E. Patterson, J. W. Roggenbuck, and A. E. Watson. 1992. Beyond the commodity metaphor: Examining emotional and symbolic attachment to place. Leisure Sciences, 14: 29-46.

Wittgenstein, L. 1958. Tractatus logico-philosophicus. London: Rutledge \& Kegan Paul.

Wolf, S. A. and J. A. Klein. 2007. Enter the working forest: Discourse analysis in the Northern Forest. Geoforum, 38: 985-998.

Yung, L., W. A. Freimund, and J. M. Belsky. 2003. The politics of place: Understanding meaning, common ground, and political difference on the Rocky Mountain Front. Forest Science, 49: 855-866. 
Table 1.0. Summary of Yellowstone River Cultural Inventory Participants by Geographic Segment

\begin{tabular}{|l|l|l|l|l|l|l|}
\hline & $\begin{array}{l}\text { GEO SEG } \\
\text { I: } \\
\text { Missouri } \\
\text { River to } \\
\text { Powder } \\
\text { River }\end{array}$ & $\begin{array}{l}\text { GEO SEG } \\
\text { Powder } \\
\text { River } \\
\text { to } \\
\text { Big Horn } \\
\text { River }\end{array}$ & $\begin{array}{l}\text { GEO SEG } \\
\text { III: } \\
\text { Big Horn } \\
\text { River } \\
\text { to } \\
\text { Laurel }\end{array}$ & $\begin{array}{l}\text { GEO SEG } \\
\text { IV: } \\
\text { Laurel } \\
\text { to } \\
\text { Springdale }\end{array}$ & $\begin{array}{l}\text { GEO SEG } \\
\text { V: } \\
\text { Springdale } \\
\text { to } \\
\text { Gardiner }\end{array}$ & $\begin{array}{l}\text { TOTAL } \\
\text { IN }\end{array}$ \\
\hline AGRICULTURAL & 22 & 22 & 16 & 12 & 14 & 86 \\
\hline CIVIC & 14 & 14 & 18 & 14 & 8 & 68 \\
\hline RECREATIONAL & 15 & 16 & 16 & 13 & 16 & 76 \\
\hline RESIDENTIAL & 15 & 11 & 16 & 15 & 19 & 76 \\
\hline $\begin{array}{l}\text { GEOGRAPHIC } \\
\text { SEGMENT TOTAL }\end{array}$ & 66 & 63 & 66 & 54 & 57 & \\
\hline NATIVE & & & & & & \\
\hline PMERICAN & & & & & & \\
\hline PROJECT TOTAL & & & & & & \\
\hline
\end{tabular}

Table 1.0. Summary of Yellowstone River Cultural Inventory Participants by Geographic Segment

\begin{tabular}{|c|c|c|c|c|c|c|}
\hline & $\begin{array}{l}\text { GEO SEG } \\
\text { I: } \\
\text { Missouri } \\
\text { River to } \\
\text { Powder } \\
\text { River }\end{array}$ & $\begin{array}{l}\text { GEO SEG } \\
\text { II: } \\
\text { Powder } \\
\text { River } \\
\text { to } \\
\text { Big Horn } \\
\text { River }\end{array}$ & $\begin{array}{l}\text { GEO SEG } \\
\text { III: } \\
\text { Big Horn } \\
\text { River } \\
\text { to } \\
\text { Laurel }\end{array}$ & $\begin{array}{l}\text { GEO SEG } \\
\text { IV: } \\
\text { Laurel } \\
\text { to } \\
\text { Springdale }\end{array}$ & $\begin{array}{l}\text { GEO SEG } \\
\text { V: } \\
\text { Springdale } \\
\text { to } \\
\text { Gardiner }\end{array}$ & $\begin{array}{l}\text { TOTAL } \\
\text { IN } \\
\text { GROUP }\end{array}$ \\
\hline AGRICULTURAL & 22 & 22 & 16 & 12 & 14 & 86 \\
\hline
\end{tabular}




\begin{tabular}{|l|l|l|l|l|l|l|}
\hline CIVIC & 14 & 14 & 18 & 14 & 8 & 68 \\
\hline RECREATIONAL & 15 & 16 & 16 & 13 & 16 & 76 \\
\hline RESIDENTIAL & 15 & 11 & 16 & 15 & 19 & 76 \\
\hline $\begin{array}{l}\text { GEOGRAPHIC } \\
\text { SEGMENT TOTAL }\end{array}$ & 66 & 63 & 66 & 54 & 57 & \\
\hline $\begin{array}{l}\text { NATIVE } \\
\text { AMERICAN }\end{array}$ & & & & & & 7 \\
\hline PROJECT TOTAL & & & & & & 313 \\
\hline
\end{tabular}

